DOI

\title{
ІМУНОПАТОГЕНЕТИЧНА РОЛЬ ІНТЕРЛЕЙКІНУ 6, 8 ТА ФАКТОРА НЕКРОЗУ ПУХЛИН-АЛЬФА У РОЗВИТКУ АДЕНОМІОЗУ
}

\author{
๑Л. М. Маланчук, В. М. Мартинюк
}

ДВНЗ «Тернопільський державний медичний університет імені І. Я. Горбачевського МОз Украӥни»

РЕЗЮМЕ. На сучасному етапі розвитку науки значна увага приділяється вивченню дисбалансу цитокінів при різних фізіологічних та патологічних процесах, аутоімунних та алергічних реакціях. Доведено, що проліферація ендометріоїдних клітин відбувається за умови, якщо в жінки існують порушення клітинного імунітету. У статті висвітлено питання імунопатогенетичної ролі інтерлейкіну 6, 8 та ФНП-а у розвитку генітального ендометріозу.

КЛЮчОВІ СЛОВА: цитокіни, ФНП-а, аденоміоз.

Вступ. Проблема доброякісних процесів матки набула особливої актуальності, що обумовлено зростанням частоти даної патології та порушенням генеративної функції організму жінки. Складні соціально-економічні та несприятливі екологічні умови, неадекватна репродуктивна поведінка призводять до зростання частоти генітального ендометріозу $[1,7]$. Аденоміоз - одне 3 найпоширеніших гінекологічних захворювань, однак, незважаючи на успіхи в його діагностиці, на сьогодні не існує єдиного стандарту лікування, що обумовлено як невирішеними проблемами патогенезу даного захворювання, так і традиційними уявленнями про неважливу роль матки при реалізованій репродуктивній функції $[2,4,5]$. Враховуючи те, що у сучасних соціально-економічних умовах збільшується відсоток жінок, для яких питання репродуктивної функції залишається актуальним у віці понад 40 років, існує потреба у подальшому вивченні етіології та патогенезу ендометріозу. Це актуальна проблема в умовах сьогодення України - як у науковому, так і в практичному відношенні. На сучасному етапі розвитку науки значна увага приділяється вивченню ролі цитокінів при аденоміозі [3], адже вони відіграють роль міжклітинних медіаторів у розвитку імунної відповіді при різних фізіологічних та патологічних процесах, аутоімунних, алергічних, про- та протипухлинних реакціях. Доведено, що імплантація ендометріоїдних клітин і їхня проліферація відбувається за умови, що в жінки $\epsilon$ порушення гуморального та клітинного імунітету $[6,8]$.

Метою нашої роботи було встановити патогенетичну інформативність ступеня продукції цитокінів сироватки крові - інтерлейкінів 6, 8 та ФНП- $\alpha$ у жінок з генітальним ендометріозом.

Матеріал і методи дослідження. Нами обстежено 40 жінок віком від 27 до 45 років з генітальним ендометріозом. Клінічна частина роботи виконана на базі відділення ТОКПЦ «Мати і дитина", лабораторна діагностика - в Міжкафедраль- ній науково-клінічній лабораторії ДВНЗ «Тернопільський державний медичний університет імені І. Я. Горбачевського МОЗ України». Контрольна група була сформована із 20 жінок, при обстеженні яких генітальний ендометріоз був виключений, а також без клінічних проявів оваріо-менструальної дисфункції. У всіх пацієнток було отримано добровільну інформовану згоду на забір венозної крові і використання їі для проведення дослідження. Визначення рівня інтерлейкінів в сироватці крові проводили методом імунноферментного аналізу (ІФА) з використанням тест-системи для ІФА. Діагноз ендометріозу був встановлений на основі клінічних, лабораторних ознак та даних ультразвукового дослідження.

Результати й обговорення. У 70 \% пацієнток з аденоміозом спостерігали порушення менструального циклу. Тяжкі менструальні кровотечі відмічались у 16 (57 \%) пацієнток. Мажучі кров'янисті виділення до або ж після менструації були у 12 (43\%) жінок. На дисменорею скаржилась майже половина обстежуваних пацієнток. Для оцінки вираженості больового синдрому використовували шкалу С. М. Mac Laverty, R. W. Shaw (1995), яка виділяє три ступені тяжкості больового індексу (за сумою балів): легкий - до 3 балів, середній 4-6 балів, тяжкий - 7-9 балів. У 25 \% обстежених пацієнток відмічали легкий ступінь, а в 75 \% - середній. Ультразвукове дослідження органів малого таза проводили усім пацієнткам з аденоміозом, при якому відмічалось збільшення передньозаднього розміру матки та округлість її форми. У $50 \%$ обстежених жінок ендометріоз поєднувався 3 фіброзно-кістозною мастопатією. Аналізуючи спадковий анамнез у групі жінок з аденомізом ми виявили, що у 85 \% пацієнток були різні види гінекологічної патології у родичів першої лінії: лейоміома матки - у $26 \%$, генітальний ендометріоз майже в $53 \%$ жінок, новоутворення органів малого таза - у 23, $5 \%$, а доброякісні захворювання молочних залоз - практично у 80 \%. Аналізуючи 
Огляди літератури, оригінальні дослідження, погляд на проблему

одержані показники цитокінів, встановили, що в імуномодуляторів вірогідно відрізняються від поусіх жінок з аденоміозом параметри ендогенних казників у крові здорових жінок (табл. 1).

Таблиця 1. Показники імунного статусу у жінок досліджуваних груп

\begin{tabular}{|c|c|c|c|}
\hline Показник & $\begin{array}{c}\text { Група жінок з аденоміозом } \\
\mathrm{n}=40\end{array}$ & $\begin{array}{c}\text { Група контролю } \\
\mathrm{n}=20 \\
\end{array}$ & Лабораторна норма \\
\hline ІЛ-6 (пг/мл) & $14,7 \pm 0,18$ & $7,4 \pm 0,2$ & до 10 пг/мл \\
\hline ІЛ-8 (пг/мл) & $148,24 \pm 2,4$ & $21,8 \pm 1,2$ & до 30 пг/мл \\
\hline ФНП- $\alpha$ (пг/мл) & $5,25 \pm 0,16$ & $3,5 \pm 0,12$ & до 5 пг/мл \\
\hline
\end{tabular}

У групі хворих на генітальний ендометріоз рівень інтерлейкіну-6 (ІЛ-6) у 2,0 рази достовірно перевищує показник у групі практично здорових пацієнток.

При дослідженні вмісту інтерлейкіну-8 було встановлено, що його концентрація у сироватці крові майже у 7 разів вища, порівняно із показниками здорових жінок. Такі результати можуть свідчити про виражену участь клітин неспецифічної резистентності у реалізації запалення при генітальному ендометріозі.

У групі пацієнток з аденоміозом спостерігалось підвищення ФНП- $\alpha$ у 1,5 раза, що є сприятливою прогностичною ознакою для перебігу запалення. Адже відомо, що фактор некрозу пухлин має широкий спектр регуляторної активності і виражену плейотропну дію. Також ФНП- $\alpha$ суттєво впливає на диференціацію, проліферацію та активацію клітин у ділянці запалення. А значне підвищення його концентрації в сироватці крові асоціюється з дисфункцією внутрішніх органів та можливим розвитком септичного стану.

Висновки. У жінок 3 аденоміозом відмічено помірне підвищення рівня ФНП- $\alpha$ та інтерлейкіну-6 в сироватці крові, що свідчить про адекватну цитокінову регуляцію імунної відповіді при запальному процесі. Оскільки первинною функцією інтерлейкіну-8 є залучення нейтрофільних гранулоцитів до місць запалення, то висока його концентрація вказує на значну активацію неспецифічної резистентності організму.

Перспективи подальших досліджень. Вивчення факторів імунної регуляції $\epsilon$ перспективним для подальших наукових досліджень в аспекті використання їх як можливих маркерів неінвазивної діагностики генітального ендометріозу.

\section{ЛІТЕРАТУРА}

1. Адамян Л. В. Эндометриозы : руководство для врачей / Л. В. Адамян, В. И. Кулаков, Е. Н. Андреева. М. : Медицина, 2006-416 с.

2. Крамарева Н. Л. Значение компонентов иммунной системы и генетических факторов в патогенезе и терапии наружного генитального эндометриоза : автореферат дисс. на соиск. уч. ст. канд. мед. наук / Н. Л. Крамарева. - СПб., 2002. - 24 с.

3. Линде В. А. Иммунологические аспекты эндометриозов : обзор литературы / В. А. Линде, Н. А. Татарова, О. И. Гришанина // Проблемы репродукции. - 2008 № 4 - С. 74-77.

4. Лобанова О. Т. Генетические и иммунологические аспекты внутреннего эндометриоза : автореф. дис. на соискание науч. степени канд. мед. наук: спец.

14.00.01/ О. Т. Лобанова. - М., 2003. - 22 с.

5. Berkkanoglu M. Immunology and endometriosis / M. Berkkanoglu, A. Arici //Am. J. Reprod. Immunol.-2003.Vol. 50. - P. 48-59.

6. Dmowski P. W. Immunology of endometriosis / P. W. Dmowsli, D. P. Braun // Best Pract. Res. Clin. Obstet. Gynaecol. - 2004. - Vol. 18 (2). - P. 245-263.

7. Haider S. Human tumour necrosis factor: physiological and pathological roles in placenta and endometrium / S. Haider, M. Knofler // Placenta. - 2009. - Vol. 30 P. 111-123.

8. Immunological factors and their role in the genesis and development of endometriosis. / C. Siristatidis, C. Nissotakis, C. Chrelias [et al.] // J. Obstet Gynaecol Res. 2006. - Vol. 32 (2). - P. 162-170.

\section{IMMUNOPATHOGENETIC ROLE OF INTERLEUKIN 6, 8 AND TUMOR NECROSIS ALPHA FACTOR IN THE DEVELOPMENT OF ADENOMYOSIS}

\section{@L. M. Malanchuk, V. M. Martyniuk \\ SHEI «Ternopil State Medical University by I. Ya. Horbachevsky of MPH of Ukraine»}

SUMMARY. At the present stage of scientific development significant attention is paid to the imbalance of cytokines in various physiological and pathological processes, autoimmune and allergic reactions. It was proved, that the proliferation of endometrial cells is provided, if the women have violations of cellular immunity.

KEY WORDS: cytokines, TFN-6, adenomyosis. 